UDC 001.32(477):930.85(477.6)]“1929/1932”:070

DOI: doi.org/10.21272/shaj.2018.i31.p.39

MARYNA O.PRYN

$\mathrm{PhD}$ (History), Vernadsky National Library of Ukraine (Ukraine)

\title{
ALL-UKRAINIAN ACADEMY OF SCIENCES IN PROJECT "PUBLIC PATRONAGE OF KYIV REGION OVER THE STALIN REGION" (1929-1932): ON THE MATERIALS OF THE LOCAL PRESS
}

\begin{abstract}
The article describes a complex of activities of cultural-educational and scientific institutions, known as "public patronage of Kyiv region over the Stalin region". The chronologically active phase of its implementation coincides with the years of the first five-year plan from 1929 to 1932 . Further it was transformed into a social orders format. The aim of the research, based on the analysis of the periodicals of Kyiv, Stalin, Mariupol, Lugansk and the journal "News of the All-Ukrainian Academy of Sciences", was to investigate the cooperation between the Kyiv's institutions and factories and the coalindustrial region of Ukraine - Donbas, which initially became the form of cultural charity assistance, subsequently turned into scientific and practical assistance to miners and metallurgists of the Donbas; to define the role of All-Ukrainian Academy of Sciences in this process, which began on the wave of Ukrainization and the first five years plan of industrialization. The patronage rapidly transformed from a predominantly educational and cultural to a scientific and practical project on assistance in solving the problems of the development of industry in the Donbas. The need to maintain the pace of implementation of the plan's tasks for the first five years of industrialization promoted the implementation of progressive technology development projects, strengthening the role of scientific institutions of All-Ukrainian Academy of Sciences in the implementation of technical problems. Two main directions of the implementation of the cultural and scientific project have been investigated: activities of education and culture institutions on the final elimination of illiteracy, raising the level of culture in the region, and the practical contribution of All-Ukrainian Academy of Sciences scientific institutions to the development of the Donbas industry. In spite of the fact that the public patronage had many disadvantages: low level of planning, poor control over the realization of the obligations, the high ideology influence to the cultural component of patronage, it had a substantial positive result. All-Ukrainian Academy of Sciences, as the flagship of Ukrainian science, and its scientists made a significant contribution to the development of mechanization of production process in factories and mines of region, improvement of the state of occupational health and safety, the study of harmful working conditions in production, improvement of living conditions and improvement of sanitary standards of life of the population, etc. In addition to the development of industry, the scientists of the All-Ukrainian Academy of Sciences activity made $f$ great contribution to the development of the cultural sphere: the network of libraries and the development of the Stalin Local History Museum. A promising research direction to deepen and elaborate information on the participation of All-Ukrainian Academy of Sciences institutions in Donbass assistance is the studied of archival documents of scientific archives of institutions that directly participated in the implementation of the scientific part of patronage.
\end{abstract}

Keywords: All-Ukrainian Academy of Sciences (VUAN), patronage, Donbas, D.K.Zabolotny, P.P.Kurinny, science, culture, museum. 
ПРИНЬМ.О.

Кандидат історичних наук, Національна бібліотека України імені В.І. Вернадського (Україна)

\section{ВУАН У ПРОЕКТІ “ШЕФСТВО ГРОМАДСЬКОСТІ КИЇВЩИНИ НАД СТАЛІНЩИНОЮ” (1929-1932): ЗА МАТЕРІАЛАМИ МІСЦЕВОЇ ПРЕСИ}

Анотація. У роботі висвітлюється комплекс заходів культурно-освітніх та наукових установ, відомий як “Шефство громадськості Київични над Сталінщчиною”, хронологічно активна фаза реалізачії якого співпадає з роками першої n'ятирічки з 1929 р. до 1932 р., надалі трансформуючись у формат сочзамовлень. Досліджено два основні напрями втілення культурного та наукового проекту: заходи установ освіти та культури з остаточної ліквідації неписьменності, підняття рівня культури в регіоні та практичний внесок наукових установ ВУАН у розвиток промисловості Донбасу.

Ключові слова: Всеукраїнська академія наук (ВУАН), шефство, Донбас, Д.К.Заболотний, П.П.Курінний, наука, культура, музей.

ПРЫНЬ М.О.

Кандидат исторических наук, Национальная библиотека Украины имени В.И. Вернадского (Украина)

\section{ВУАН В ПРОЕКТЕ “ШЕФСТВО КИЕВСКОЙ ОБЩЕСТВЕННОСТИ НАД СТАЛИНЩИНОЙ” (1929-1932): ПО МАТЕРИАЛАМ МЕСТНОЙ ПРЕССЫ}

Аннотация. В работе освещзается комплекс мероприятий культурно-образовательных и научных учреждений, известный как "Шефство Киевской обшественности над Сталинщчиной”, хронологически активная фаза реализации которого совпадает с годами первой пятилетки с 1929 2. по 1932 г., в дальнейшем трансформируясь в формат соизаказов. Исследованы два основные направления реализации культурного и научного проекта: мероприятия учреждений образования и культуры по окончательной ликвидации неграмотности, повышения уровня культуры в регионе и практический вклад научных учреждений ВУАН в развитие промышленности Донбасса.

Ключевые слова: Всеукраинская академия наук (ВУАН), шефство, Донбасс, Д.К.Заболотный, П.П.Куринной, наука, культура, музей.

Звернення до історичного досвіду взаємодії академіків із робітниками промислових і вугільнодобувних підприємств розкриває раніше невідомі грані в історії Національної академії наук України (далі - НАН України). 2018 рік - 100-річчя НАН України та 4-та річниця окупації частини Донбасу Російською Федерацією, тому дослідження внеску центральної наукової установи України - Всеукраїнської академії наук (далі - ВУАН) у розвиток Донецького регіону є вкрай актуальним.

У 1920-х роках набула поширення така форма співпраці, як шефська допомога: робітників - селянам, студентів - підприємствам та установам, робітників промислових підприємств - військовим тощо. На хвилі розгортання в Україні політики українізації та початку індустріалізації під пильну увагу громадськості Києва потрапив промисловий високоурбанізований, але освітньо та культурно нерозвинений регіон - Донбас.

Під територією з історико-географічною назвою Донбас розуміємо регіон, землі якого у 1925-1930 рр. входили до складу п’яти округ: Артемівської, Луганської, Маріупольської, Старобільської та Сталінської, у 1930-1932 рр. - до 27 районів (згодом 17 адміністративно-територіальних одиниць), на які було поділено зазначені округи та на основі яких у липні 1932 р. було створено Донецьку область.

В українській історіографії тема культурного шефства громадськості Києва над Сталіно (нині - м. Донецьк) та участь в цьому процесі ВУАН як окремий напрямок 
досліджень не розглядалася. У загальних працях з історії НАН України, зокрема двотомній монографії Н.Д. Полонської-Василенко "Українська академія наук. Нарис історії" (Полонська-Василенко, 1955; Полонська-Василенко, 1958), колективних монографіях “История Академии наук Украинской ССР” (История АН УССР, 1979), “Академия наук Украинской ССР. 1985” (АН УССР, 1986), монографії Л.В. Матвєєвої “Нариси з історії Всеукраїнської академії наук” (Матвєєва, 2003) та ін. тема шефства не розглядалася.

Джерельною базою для дослідження стали місцеві періодичні видання Києва, Сталіно, Маріуполя та Луганська - газети "Пролетарська правда", “Диктатура труда", "Приазовський пролетар" та "Луганська правда". Додатковим джерелом інформації 3 досліджуваної теми стало друковане видання ВУАН “Вісті Всеукраїнської академії наук”. Також у досліджені були використані документи з фонду “Всеукраїнський археологічний комітет” (далі - ВУАК) наукового архіву Інституту археології НАН України та фонду № 166 Центрального державного архіву вищих органів влади та управління України.

Метою даної статті є дослідження співпраці між громадськістю Києва та східного промислового регіону України - Донбасу (переважно м. Сталіно), яка спочатку полягала в культурному шефстві, а згодом переросло в науково-практичну допомогу гірникам та металургам Донбасу, визначити роль ВУАН у цьому процесі.

Початковим етапом цього дослідження є 1929 р. Саме в 1929 р. керівництву УСРР стало очевидним відставання Донбасу в процесі ліквідації неписьменності, втіленні політики українізації та в культурному розвиткові загалом. Івже в березні 1929 р. в промислових регіонах України, зокрема і в Донбасі, почалося проведення "Місячника української культури" (Месячник украинской культуры, 1929: 2). 11 березня 1929 р. делегація з 80-ти робочих кореспондентів з числа робітників промислових підприємств і представників сфери культури м. Луганськ відвідала м. Харків з метою вивчення досвіду проведення заходів 3 українізації (Луганский, 1929: 6). Під час візиту луганські делегати зустрілися з першим секретарем ЦК КП(б)У С.В. Косіором (Пролетарии Донбаса, 1929: 1) та наркомом освіти УСРР М.О. Скрипником (Крапля, 1929: 1). Одним із побажань, висловлених луганськими гостями, було сподівання на приїзд українських письменників для ознайомлення з працею шахтарів і металургів, щоб висвітлити ії в своїх творах (Жуков, 1929: 5).

На побажання трудящих у березні 1929 р. м. Сталіно відвідала група українських письменників: В.М. Сосюра, Л.С. Первомайський, А.І. Шмигельський, Н.Л. Забіла, С.О.Голованівський (Украинские писатели, 1929: 2), а в квітні в окрузі розпочався місячник української культури, який широко висвітлювався в місцевій пресі (Выступаем в поход, 1929: 3). Крім того, академік Д.І. Багалій у відкритому листі зі шпальт місцевої газети звернувся до мешканців м. Сталіно із закликом підтримати державну політику українізації та долучитися до вивчення історії України (Багалей, 1929: 3).

Як відповідь академіку в місцевій газеті “Диктатура труда” було опубліковано відкритого листа від громадськості м. Сталіно до громадськості м. Київ із проханням допомогти провести місячник української культури в Донбасі. До співпраці запрошували представників київських освітньо-культурних закладів, просили організувати пересувні музейні виставки. Заголовки говорять самі за себе: "Познакомим с украинским театром" (Познакомим, 1929: 3), “Пролетарский Киев должен помочь” (Пролетарский Киев, 1929: 2), “Киевские рабочие ждут сталинскую делегацию”, “Чего мы ждем от поездки в Киев. Наш наказ делегатам” (Киевские рабочие, 1929: 3) та ін.

29 квітня 1929 р. делегація зі Сталіно у складі представників різних промислових підприємств (600ос.) прибула до Києва. Для них було організовано масштабну зустріч із представниками громадських, партійних, наукових установ та підприємств (Первомайские гости, 1929: 2). За культурною програмою делегати, розділившись на групи, відвідали промислові підприємства Києва: заводи “Більшовик”, “Ленінська кузня”, 
“Фізико-Хемік”, трикотажну фабрику, трамвайні майстерні, тютюнові та шкіряні фабрики, взяли участь у травневих урочистостях (Хребтов, 1929: 2).

2 травня 1929 р. в колонній залі Палацу праці відбулася велика зустріч делегатів Сталінщини, представників ВУАН, Окружної ради професійних спілок (далі - ОРПС) та підприємств Києва. На ній були присутні понад 2000 учасників (Советский Киев, 1929: 3). Серед доповідачів був і Президент ВУАН академік Д.К. Заболотний, який виступив із коротким звітом про роботу ВУАН за 10 років, зауваживши про велике значення зближення науки та виробництва. Результатом заходу стала угода між ВУАН та ОРПС про початок великого освітньо-наукового проекту, який згодом отримав назву “Культурного шефства Київщини над Сталінщиною” та повинен був познайомити мешканців промислового регіону зі здобутками української культури. Угода була підписана головою ОРПС Олексієвим та Президентом ВУАН академіком Д.К. Заболотним. Також був виголошений текст звернення до представників промисловості та науки УСРР про підтримку цього проекту (Исторический поход, 1929: 1).

Угода передбачала декілька напрямів іiї реалізації: по-перше - активна участь у процесі ліквідації неписьменності в регіоні, по-друге - ознайомлення мешканців Сталінщини з роботою та досягненнями ВУАН, по-третє - знайомство населення 3 культурними здобугками, зокрема українською художньою, музичною творчістю, літературою, театром, музеями. Передбачалося надання допомоги культурним закладам Сталіно, тісний зв'язок та кураторство над місцевою пресою. Як наголошувалося в угоді, культурна допомога повинна була сприяти насамперед підвищенню продуктивності праці в основних галузях промисловості регіону-металургії та видобутку вугілля - тих основних ресурсів, вага яких дедалі зростала в умовах індустріалізації України (Громадська робота, 1929: 131-134).

На засіданні ради шефства було прийняте попереднє спільне рішення про те, які організації долучаться до цього процесу. До них відносились: ВУАН та ії установи, Київський інститут народної освіти (КІНО), Київський політехнічний інститут (КПІ), Київський інститут народного господарства (КІНГ), Державний музично-драматичний інститут імені М.В. Лисенка, Київський художній інститут (КXI), Український науковий інститут книгознавства (УНІК), Київський музей революції, Державний історикокультурний заповідник “Всеукраїнський музейний городок” (ДІКЗ ВIМ), Драматичний театр імені Івана Франка, Київська державна академічна українська опера, Київська консерваторія, капела “Думка”, Всеукраїнський союз пролетарських письменників, Секція наукових робітників (СНР), Центральна робітнича бібліотека імені ВКП(б) (ВБУ) та інші (Давайте выполнять договор, 1929: 2).

13 травня 1929 р. на засіданні Загальних зборів ВУАН академік Д.К. Заболотний проінформував присутніх про перші кроки розпочатого культурного шефства над Сталінщиною та візит делегації звідти до Києва. У промові було наголошено, що для забезпечення реалізації шефства необхідні регулярні відрядження академіків та наукових співробітників ВУАН до м. Сталіно. Крім того, була оприлюднена пропозиція запрошувати представників тамтешніх підприємств до установ ВУАН на ознайомчі екскурсії та навіть на засідання Загальних зборів ВУАН. Також було порушено питання необхідності розробки загального плану реалізації шефства та складання графіку відвідувань підприємств м. Сталіно працівниками науково-дослідних установ Київщини (Протокол, 1929: 1-24).

Для реалізації культурного шефства були окреслені головні об'єкти промисловості: 6 великих підприємств, 8 копалень; Донецький гірничий інститут, Інститут робітничої медицини, заклади освіти, Сталінський окружний музей краєзнавства, Центральна міська бібліотека, 4 палаци культури, 5 робітничих клубів, 4 багатотиражні газети та ін. Київський культвідділ Окрпрофради звернувся до всіх культурно-освітніх та наукових 
установ м. Київ з пропозицією скласти свої річні плани шефських заходів із кошторисом на їх реалізацію (Культурное шефство над Сталинщиной, 1929: 3).

Вже за місяць, у червні в м. Київ відбулося друге засідання представників ВУАН, Київського будинку вчених, РОБОСу, Київського медичного інституту та ін. 3 першими конкретними пропозиціями щодо втілення плану шефства. ВУАН запропонувала взяти участь у відвідуванні м. Сталіно представниками київських промислових підприємств, громадських і наукових установ 3 метою читання лекцій, зокрема організувати низку візитів науковців ВУАН і створити мережу робочих кореспондентів для збирання матеріалів з етнографії краю.

Всенародна бібліотека України ставила собі за мету надати методичну та практичну допомогу місцевим бібліотекам, зокрема виділивши дублетні видання для поповнення фондів. Представники Всеукраїнського товариства революційних музикантів i Державного музично-драматичного інституту імені М.В. Лисенка також планували провести активну лекційну діяльність та допомогти в роботі місцевим художнім i драматичним гурткам (Культурное шефство над Сталино, 1929: 2).

Проте найбільш нагальним питанням для вирішення проблем розвитку культурного життя Сталінської округи була і залишалася нестача кваліфікованих кадрів. Зарадити цьому ВУАН планувала організацією довгострокових відряджень до м. Сталіно своїх співробітників для практичної та методичної допомоги місцевим установам. Як дієвий засіб київській спілці РОБОС та інспектурі народної освіти доручалося направляти на роботу в культурні заклади м. Сталіно кваліфікованих фахівців, які не були задіяні в м.Київ (НА IA НАНУ. Ф. ВУАК. СПр. 294А.: 6).

Для реалізації культурного шефства науковою колегією Всеукраїнського музейного городка 10 червня 1929 р. до м. Сталіно був відряджений його директор П.П. Курінний (НА ІА НАНУ. Ф. ВУАК. Спр. 294А.: 4), вчений секретар ВУАКу та уповноважений від ВУАН у питаннях шефства. У Сталіно фактично не було реально діючого окружного музею. Тому одним з основних завдань у шефській роботі над Сталінщиною Всеукраїнського музейного городка стала організація постійної роботи крайового музею, який міг би вести повноцінну науково-дослідницьку діяльність. Перед ДІКЗ ВІМ ставилося завдання фактично розробити нову наукову експозицію місцевого музею. Наукова колегія заповідника доручила всім завідувачам відділів розробити проекти планів майбутніх структурних підрозділів Сталінського окружного музею краєзнавства. Пильну увагу приділяли й кадровому забезпеченню місцевих установ культури. Пропонувалося направляти на Донбас лекторів і запрошувати на навчання музейних працівників 3 м.Сталіно, допомагати методичною літературою місцевим закладам. Працівниками ДІКЗ BIM був розроблений статут про спеціальний потяг "Музей-Донбас" (НА IA НАНУ Ф. ВУАК. Спр. 294А.: 8-10зв.). Саме в рамках такої кадрової допомоги музейній галузі Сталінщини, стали короткострокове відрядження в 1929 р. в Сталінський окружний музей краєзнавства етнографа Олександра Якубського (Принь, Принь, 2015) та в 1930 р. мистецтвознавиці Любові Мулявки (Принь, 2014), які недовгий термін очолювали музей.

На початковому етапі реалізації шефського проекту популярною формою комунікації став обмін делегаціями. 3 нагоди святкування трьохріччя українізації газети "Комуніст" в м. Сталіно 16 червня 1929 р. проходили урочисті заходи (16 июня, 1929: 2), які відвідала київська делегація. Доповіді науковців ВУАН викликали неабияке зацікавлення серед робітників Донбасу, а неодмінний секретар ВУАН академік О.В. Корчак-Чепурківський здійснив спуск до вугільної шахти (Торжество, 1929: 3). Урочистості також відвідала делегація металургів із Маріупольської округи (16 июня, 1929: 2).

Зі свого боку на загальному зібранні робітників м. Сталіно була сформована делегація для участі у Загальних зборах ВУАН 1929 р., присвячених виборам нових академіків. 
Делегація складалася виключно з робітників та виїхала до Києва під гаслом “Академію - ближче до життя...” (Шах, 1929: 3). Делегація мала ще одну важливу місію - вона передала до ВУАН новий договір, у якому були оформлені більш конкретні очікування від шефства науковців Києва. Договір був затверджений на засіданні Сталінської окружної ради профспілок 29 червня 1929 р. та мав назву "Наказ робітників Сталінщини Всеукраїнській Академії Наук”.

Керівництво країни, визнаючи необхідність підвищення загального культурного рівня мешканців регіону, все ж основний наголос робило на конкретні практичні потреби розвитку промисловості: проведення геологічних розвідок для виявлення нових родовищ корисних копалин, вивчення процесів виробництва для їх удосконалення та практична допомога в їх раціоналізації. Представників робочої делегації хвилювали й умови та безпека праці, удосконалення техніки виробництва, вивчення шкідливості виробничих процесів та їх впливу на здоров'я працівників. Не менш болючими були проблеми водопостачання, будівництва житла та впорядкування забудови населених пунктів i будівництва шляхів (Громадська робота, 1929: 131-134).

Окрім участі у Загальних зборах ВУАН, делегати відвідали Київську державну академічну українську оперу, окружну конференцію працівників металургійної галузі та Всеукраїнський музейний городок (Три дні, 1929: 2), де показали гостям експонати музеїв тощо. Директор ДІКЗ ВІМ П.П. Курінний на зустрічі з делегатами ознайомив їх з науковоосвітньою та науково-дослідною роботою заповідника (Сталинские делегаты, 1929: 2). 3 членами делегації обговорювалися і практичні питання участі Всеукраїнського музейного городка в шефській допомозі м. Сталіно, серед яких - організація пересувної виставки та практична допомога Сталінському окружному музею краєзнавства (Вместо церковно-монархической агитации, 1929: 2). Загалом червнева поїздка делегації робітників м. Сталіно до Києва широко та детально висвітлювалася на шпальтах місцевої газети “Диктатура труда” (Союз индустрии, 1929: 3).

Одним із важливих питань, що реалізовувались у м. Сталіно у 1929 р. була науковопопуляризаційна та ознайомча робота представників ВУАН. Протягом всього року в газеті “Диктатура труда” з'явилася спеціальна нова рубрика під назвою “Як живе та працює Академія. Всеукраїнська академія наук розповідає про себе трудящим Сталінщини”, яка займала цілу сторінку та містила низку інформаційно-ознайомчих статей щодо ролі та значення науки в різних галузях промисловості. Зокрема, академік Д.К. Заболотний підготував статтю "Розвиток науки та эї завдання", академік М.С.Грушевський опублікував статтю “Академія вивчатиме минуле Донбасу”. Також були опубліковані статті академіків Д.О. Граве "Математик-інженер-робітник. Значення математики у виробництві” (Граве, 1929: 5); О.В. Фоміна “Ботаніка на службі народньому господарству" (Фомін, 1929: 4) та багато ін. Поглибити знайомство з Академією намагалися й через невеликі біографічні довідки про академіків П.А. Тутковського (Академик Тутковский, 1929: 5), Д.О. Граве (Академик Граве, 1929: 3), М.М. Крилова (Академик Крылов, 1929: 3), Б.І. Срезневського (Академик Срезневский, 1929: 4), В.О.Плотнікова (Академик Плотников, 1929: 4), М.О. Скрипніка (Теоретик, 1929: 3), Г.М. Кржижановського (Творец электрификации, 1929: 3) та ін., розміщені в газеті.

Протягом 1929 р. було здійснено виїзди чотирьох мистецьких груп Державного музично-драматичного інституту імені М.В. Лисенка, музичного квартету імені Чайковського, двічі приїжджав Український пересувний робітничий театр. Тривалий час на практиці в клубах і палацах культури Сталінщини перебували 30 студентів Київського художнього інституту, також у довгострокові відрядження сюди було направлено 10 українознавців, 5 викладачів іноземних мов, 3 керівники музичних $\mathrm{i}$ драматичних гуртків. Чотири делегати з м. Сталіно навчались у Києві на антирелігійних 
курсах при Всеукраїнському музейному городку (НА ІА НАНУ. Ф. ВУАК, Спр. 294А.: 1). У жовтні 1929 р. в м. Сталіно експонувалася друга Державна пересувна всеукраїнська художня виставка НКО УСРР, де були представлені твори художнього мистецтва, графіка, скульптури тощо (2-га Всеукраїнська, 1929: 5). Представники Київської кінофабрики Всеукраїнського фотокіноуправління під керівництвом Дзиги Вертова, відомого кінорежисера, одного із засновників і теоретиків документального кіно, провели зйомки документального фільму на Макіївському металургійному заводі (Цейтлин, 1929: 5).

У 1930 р. практика відвідування м. Сталіно делегаціями з Києва продовжилася. Для участі в першотравневих святкових заходах 1-2 травня 1930 р. м. Сталіно відвідала делегація з 23 представників Київщини. У складі делегації переважали представники київських підприємств, також були співробітники Державного музично-драматичного інституту імені М.В. Лисенка та Київського художнього інституту. Від ВУАН було делеговано двох представників - В.В. Білого, співробітника Фольклорно-етнографічної комісії та співробітника Геологічного інституту Кандуренкову. Після урочистостей делегати відвідали окремі підприємства, шахти та заводи (Звідомлення, 1930: 33-38).

У Києві на травневі свята 1930 р. було зібрано звітну нараду, яка підвела підсумки шефської роботи за рік. Протягом року шефства м. Сталіно відвідали представники різних культурно-освітніх і наукових установ Києва передусім з метою ознайомлення з регіоном, його культурними та виробничими потребами. Були окреслені першочергові проблеми регіону: водопостачання, боротьба з епідеміями, шкідливі умови праці, удосконалення виробничих процесів на промислових підприємствах. Вкотре прозвучало нагадування науковим установам про необхідність активно долучитися до практичних заходів щодо їх вирішення (Про стан, 1930: 2).

7-8 листопада 1930 р. в колонній залі профспілок Київщини відбулися збори представників промисловості Київщини, Сталінщини та наукової громадськості Києва. На зборах були присутні представники колгоспів Київщини, гості 3 міст Дніпропетровська, Харкова, Одеси, Кривого Рогу, Москви та ін. На зборах зі звітною доповіддю виступив неодмінний секретар ВУАН академік О.В. Корчак-Чепурківський. 3 огляду на цей звіт можна констатувати, що ВУАН врахувала реальні потреби промислового регіону та спрямувала зусилля своїх науковців на вивчення проблемних питань та шляхів їх вирішення на Донбасі (Іваницький, 1930: 26-27).

У той час існувала дуже гостра проблема забезпечення житлом працівників промислових підприємств Сталінщини. Частина населення все ще мешкала в землянках. Протягом 1930 р. Інститут будівельної механіки ВУАН частину своїх досліджень зосередив на проблемах виготовлення будівельних матеріалів із відходів металургійного виробництва, зокрема жужільної цегли та цементу. Для практичних дослідів 3 цих матеріалів було збудовано експериментальний будинок для працівників.

Питаннями з охорони праці на шахтах Донбасу опікувалася кафедра теорії пружності. Науковці кафедри регулярно проводили консультації з організації охорони праці на виробництві для шахт регіону, розробили “Довідник з технічної механіки для гірничих техніків”. Кафедра хімії проводила досліди з виготовлення метилового спирту 3 допомогою елементів коксового газу, який у великій кількості вироблявся під час коксування кам'яного вугілля.

Крім того, кафедра гідрології ВУАН та Інститут водного господарства України опікувалися болючою проблемою водопостачання, особливо для промислових підприємств. Були проведені розвідувальні роботи, збудована земляна гребля на р. Вовча для забезпечення Сталінського металургійного комбінату водою. Для забезпечення водою Макіївського металургійного комбінату на р. Кринка також було збудовано греблю, прокладено 26 км водогону. Також були проведені аналогічні роботи для забезпечення водою 
Алчевського металургійного комбінату. Розроблялися проекти побудови водосховищ на низці місцевих річок: Вовча, Кальміус, Казенний Торець, Лугань, Біла та ін. Одночасно проводилися роботи з метою забезпечення населення технічною та питною водою.

Інститут мікробіології та епідеміології Народного комісаріату охорони здоров'я зі свого боку проводив санітарно-гігієнічні дослідження води та грунту. Кафедра гігієни й санітарії ВУАН проводила статистичні дослідження про рівень смертності; у цьому ж напрямі працював й Демографічний інститут. Кафедра патологічної анатомії взяла шефство над кафедрою патологічної анатомії Сталінського медичного інституту. До музею інституту була передана серія патолого-анатомічних та патолого-гістологічних препаратів для використання їх у навчальному процесі, а також під час науково-популярних лекцій.

Сталінському окружному музею краєзнавства Біологічним інститутом були передані експонати морської фауни Північного Льодовитого океану. Зважаючи на континентальний клімат регіону 3 посушливим літом та холодною малосніжною зимою, на кафедрі ботаніки під керівництвом академіка О.В. Фоміна працювали над розведенням та акліматизацією різних видів дерев і кущів, які б витримували доволі суворі кліматичні умови Донбасу. Восени 1929 р. та влітку 1930 р. відбулась перша вдала спроба озеленення території м. Сталіно. Найбільш життєздатними стали насадження білої акації, декількох видів клену та дикої маслини (Берсен, 1930: 32-35).

Достатньо активно проводилася й лекційна робота. У рамках проведення двотижневика “Техніка - масам" у жовтні 1929 р. до м. Сталіно прибули 6 академіків ВУАН, які прочитали низку лекцій. Три лекції інженера-дослідника будівельної механіки академіка К.К. Симінського були присвячені проблемам будівництва та тривалості служби споруд і механізмів; академік О.В. Палладін у своїй лекції "Хімія життя" познайомив слухачів із основами біохімії; академік С.В. Оппоков, директор Інституту водного господарства України, прочитав лекцію “Вода й водне господарство, зокрема в Донбасі”. Проблеми озеленення степового краю, який потерпав від пилових буревіїв, висвітлив відомий український геоботанік Ю.Д. Клеопов (Киевские культшефы, 1929: 5). Професор А.С. Синявський, керівник географо-економічної експедиції Комісії по дослідженню території Дніпрельстану прочитав 31 лекцію 3 питань будівництва Дніпрельстану, його соціально-економічних перспектив та індустріалізації загалом. Низку лекцій на тему української культури прочитав український поет, літературознавець і перекладач М.О. Драй-Хмара. Також науковці відвідали й м.Артемівськ (нині - м. Бахмут), де також зробили доповіді для робітників академіки О.В. Палладін та С.В. Оппоков (Украинские ученые, 1929: 2).

Загалом за 1929-1930 рр. було здійснено 6 виїздів бригад, до складу яких входили 29 працівників ВУАН. Серед 91 зробленої науковцями доповіді 79 припадало на науковопопулярні лекції. Лекційна тематика була переважно присвячена проблемам індустріалізації, соціально-економічним проблемам, питанням культури (Берсен, 1930: 36-39).

Півторарічний практичний досвід співпраці науковців ВУАН із робітниками промислових підприємств Сталінської, Артемівської, Маріупольської округ виявив необхідність корегування та деталізації напрямів шефської допомоги. Також давалася взнаки відсутність координації роботи з обох боків. I вже на шефських зборах 7-8 листопада 1930 р. було укладено новий договір про шефську роботу.

Промисловість країни потребувала від Донбасу насамперед енергетичних ресурсів, а саме великої кількості вугілля. Для наукових установ ВУАН першочерговим стало завдання вирішення проблем механізації виробництва, особливо вугільної галузі, поширення вуглевидобувних механізмів: врубових машин, конвеєрів, скреперів тощо. Поряд із розвитком гірничовидобувної промисловості наголошувалося на необхідності розширення вивчення надр Донбасу. Не оминалося в договорі й питання 
переобладнання та реконструкції існуючої металургійної бази, системи водопостачання для забезпечення технологічних процесів.

В умовах високих темпів зростання промисловості в Україні все гостріше проявлялася одна 3 головних проблем Донбасу - нестача висококваліфікованих робітників. Для її вирішення ВУАН та інші наукові установи планували організувати лекції для інженерно-технічних працівників на теми, які стосувалися металургійної, вугільної та хімічної промисловості. Також поліпшити ситуацію повинні були технічні видання для середньої інженерної ланки та популярна література для робітників. Новою угодою передбачалося детальніше дослідження умов праці та побутових умов життя, розробка питань раціоналізації громадського та лікувального харчування, диспансеризації, особливо представників шкідливих професій: шахтарів, робітників гарячих цехів і хімічної промисловості.

Продовжувалася й культурна співпраця: допомога бібліотекам, підвищення кваліфікації вчителів, допомога в справі дошкільного виховання. Не залишився поза увагою й напрям пропаганди: продовжувалося шефство над багатотиражними періодичними виданнями, надавалася методична та практична допомога представникам партійного керівництва (Новий договір, 1930: 39-41).

3 прийняттям Конституції УСРР 1929 р. та розпочатою виборчою кампанією 19301931 рр. ще одним напрямом надання допомоги східному регіону стали консультації щодо організації виборчого процесу. У січні 1931 р. для ознайомлення з роботою міськради та міськвиборчкому Київ відвідала делегація з м. Сталіно. У своїй доповіді делегати відзвітувалися про організацію виборів на підприємствах, а також зробили акцент на економічні показники як реалізацію шефської роботи зі свого боку (Пролетарі Сталінщини, 1931: 3). Продовжувала роботу рада шефства; у 1931 р. було ухвалено проводити роботу ради за секторами: науковим, технічним, літературним, освітнім, друку, мистецьким, художнім, музейно-антирелегійним, санітарно-побутовим (Бригадир, 1931: 3).

Одним із нових методів реалізації шефства стала організація так званих культпотягів, культешелонів до Донбасу. Ще у 1930 р. на базі Всеукраїнського музейного городка почався процес створення музею-потягу “Музей - Донбас", який повинен був протягом чотирьох місяців 1931-1932 рр. обслуговувати населення Донбасу. До створення потягу були залучені Національний геологічний музей ВУАН і Всеукраїнський історичний музей імені Т. Шевченка. Фінансували проект Всеукраїнська рада професійних спілок та Народний комісаріат освіти УСРР. Згідно зі статутом музей-потяг повинен був мати 4 відділи-вагони: перший вагон висвітлював теми з історії та економіки УСРР, другий - проблеми технічної реконструкції СРСР, третій вагон був присвячений темі класової сутності походження релігії і безвірницького руху в УСРР, експозиція четвертого розкривала основні проблеми мистецтва в історичному аспекті (НА ІА НАНУ. Ф. ВУАК. Спр. 294А: 8-9). Закінчення роботи зі створення пересувної експозиції передбачалося на грудень 1931 р. (Культробота на допомогу, 1931: 2) Однак аналіз місцевої преси дає підставу вважати, що цей проект у первинному задумі так і не було остаточно реалізовано.

2 січня 1931 р. було сформовано культурно-господарчий ешелон до м. Сталіно, який складався з 25 товарних і пасажирських вагонів. До складу делегації входило 115 учасників, які були об'єднані за тематичними бригадами. Зокрема, бібліотечна бригада складалася з 18 осіб і проводила роботу на всіх великих шахтах та підприємствах регіону, особливу увагу приділивши Центральній міській бібліотеці м. Сталіно. Бригада артистів Драматичного театру імені Івана Франка у складі 4 учасників і квартет Київського радіоцентру дали 21 концерт в робітничих клубах на підприємствах Донбасу. Бригада Державного музично-драматичного інституту імені М.В. Лисенка надавала консультаційну допомогу місцевим клубним гурткам та зіграла 17 вистав на 
підприємствах; літературна бригада у складі двох письменників сконцентрувала свою увагу на Сталінському металургійному заводі, зробивши 9 доповідей на тему літератури, 2 лекції з українознавства та провівши 3 творчі вечори. Крім того, бригада науковців від ВУАН також зосередила роботу на великому підприємстві Сталінському металургійному заводі, де були проведені лекції з української мови та додаткові заняття з вчителями української мови. Інженер у хімічній галузі також проводив активну роботу на цьому заводі. Він надавав консультації, проводив відбір матеріалу для лабораторних досліджень, обстежив доменний цех заводу.

Бригада Київського радіоцентру надала практичну допомогу в радіофікації підприємств міста, бригада нацменробітників обстежувала стан роботи 3 нацменшинами на підприємствах, бригада студентів Київського державного інституту кінематографії працювала на шахтах і великих промислових підприємствах, знімаючи хронікальні кіно та фотозйомки, демонструючи фільми та допомагаючи в організації місцевої самодіяльності. Активну просвітницьку та пропагандистську роботу проводив колектив вагону-клубу та антирелігійної виставки, бригада студентів індустріального робфаку тощо (Хуторян, 1931: 3).

Наприкінці березня 1931 р. редакція газети "Пролетарська правда" запропонувала організувати та відправити до 1 травня ще один невеликий культешелон на 1-2 вагони (Зельдович, Чернявський, 1931: 3). Ця пропозиція була підтримана та реалізована і 12 квітня 1931 р. згаданий потяг вирушив до м. Сталіно. Незважаючи на складнощі комплектування, до складу делегації ввійшли 60 учасників: 3 представники ВУАН, представники установ культури, освіти та лікарі (Лицем до Донбасу, 1931: 3). Від ВУАН в заході взяли участь науковий співробітник Інституту будівельної механіки Ф.П. Бєлянкін, інженер Хімічної лабораторії Іванов та хімік С.В.Гончаров. За час відрядження у складі культешелону вони проводили консультаційні зустрічі з місцевим інженерно-технічним персоналом, вивчали роботу лабораторій підприємств тощо (Смченко, Цупик, Харкін, 1931: 3).

Загалом Інститут будівельної механіки ВУАН ще з 1929 р. доволі активно співпрацював із металургійними підприємствами Сталіно. У планах на 1931 р. Інститут ставив собі за мету за наявності фінансування продовжити досліджувати якість та міцність споруджень і устаткування, виявляти та вивчати причини виходу з ладу станків, досліджувати вібраційні явища. Окремим напрямом наукових інтересів цього інституту стало вивчення властивостей будівельних матеріалів, виготовлених 3 відходів металургійного виробництва (Наука на допомогу, 1931: 3). Хімічна лабораторія ВУАН також продовжувала розробку наукових тем прикладного спрямування. Були заплановані для розробки теми: “Використання антраценової фракції” та “Синтези вищих алкоголів 3 коксових газів” (Ємченко, Цупик, Харкін, 1931: 3).

Частина наукових установ ВУАН запланувала для розробки наукові теми, пов'язані з практичним дослідженням актуальних для Донбасу тем. Серед них: Машинобудівний інститут, Науково-дослідний інститут хімії, Хіміко-технологічний інститут. Але деякі науково-дослідні інститути енергетичної, геологічної галузі цей напрямок роботи проігнорували (Денисенко, Шапошнік, 1931: 3).

Загалом у 1931 р. ВУАН було заплановано декілька відряджень до Сталіно та Макіївки. У травні - групи науковців у складі наукового співробітника Інституту будівельної механіки ВУАН, геофізика, трьох хіміків і геолога; червнева бригада повинна була складатися з наукового співробітника кафедри математики, наукового співробітника Інституту будівельної механіки ВУАН та хіміка, липнева - із трьох хіміків та інженера гірничої електрифікації (Бригади ВУАН, 1931:3).

На тлі стрімкого зростання промисловості та кількості населення промислових 
східних округ все актуальніше ставало питання розробки та встановлення санітарних норм та поліпшення медичного обслуговування населення. Протягом місяця, з 15 червня до 15 липня 1931 р., на Сталінщині працювала бригада Медичного циклу ВУАН та Інституту експериментальної біології та патології ВУАН на чолі з президентом ВУАН академіком О.О. Богомольцем. До складу бригади також входили проф. М.Д.Стражеско, Л.М. Левитський, С.К. Капран і В.Х. Василенко. Були налагоджені тісніші контакти з Донецьким інститутом патології та гігієни праці. Від серпня 1931 р. до вересня 1932 р. розробляли найактуальніші теми із санітарно-гігієнічних питань, із досліджень проблем стану здоров'я працівників гарячих цехів та глибоких шахт, граничних норм шкідливих газів тощо. Під час загальних зборів лікарів і наукових робітників регіону О.О. Богомолець зробив декілька доповідей, серед яких “Сучасний стан проблеми переливання крові”, проф. М.Д. Стражеско - “Соціальне значення і клініка ревматизмів та ендокардитів”, “Захворювання серцево-судинної системи та сучасні методи їх визначення" (Бригада медциклу, 1931:3) та ін.

Науково-технічний сектор Ради шефства, очолюваний ВУАН, відмовившись після другого культешелону від форми участі змішаних колективів, сконцентрувався на формуванні наукових груп за окремими проблемними напрямками. Загалом упродовж року було сформовано п’ять бригад загальною кількістю 19 осіб, у роботі яких взяв участь, зокрема й Президент ВУАН академік О.О. Богомолець. Також над проблемами озеленення території систематично працювала група з двох чоловік. Освітній сектор Ради шефства разом зі спілкою РОБОС та НКО УСРР надіслав на постійну роботу 42 особи та бригаду з 14 осіб для методичної роботи. Завдяки активній участі Київського інституту пролетарського мистецтва в міст Макіївці, Сталіно та Луганську були організовані три вечірні художні робітничі факультети (Наш досвід, 1931: 3).

Керівник музейно-антирелігійного сектору ради шефства П.П. Курінний під час свого візиту до м. Сталіно та Петрівського рудника зробив доповідь про науково-дослідну роботу Всеукраїнського музейного городка. Цей заповідник брав активну участь у розвитку музейної справи в м. Сталіно, яка знаходилася на дуже низькому рівні. Протягом 1931 р. на допомогу Сталінському окружному музею краєзнавства був відряджений один співробітник заповідника. Також були підготовлені та направлені на заводи три пересувні виставки. Протягом трьох місяців у регіоні працювали й дві пересувні антирелегійні виставки-вагони з лекторами (Культробота, 1931: 2).

У листопаді 1932 р. на Донбасі був відкритий Святогірський філіал Всеукраїнського музейного городка (або Вседонбаський антирелігійний музей при 1-му Всеукраїнському будинку відпочинку), який знаходився на території колишнього Святогірського монастиря. Фондова колекція музею була сформована 3 речей, вилучених безпосередньо з монастиря та церков в Ізюмі та наданих із фондів Всеукраїнського музейного городка й налічували близько 1000 од. зб. Музей активно долучився до антирелігійної пропаганди, його співробітники проводили масову антирелігійну роботу на підприємствах Сталіно, менш ніж за рік прочитавши 107 лекцій (ЦДАВО України. Ф. 166. Оп. 10. Спр. 571: 8-47.). Активну роботу проводили й мистецький, літературний і санітарно-побутовий сектори Ради шефства (Культробота, 1931:2).

1932 рік став роком закінчення першої п'ятирічки та початку активного процесу планування другої. Слід зазначити, що ВУАН не стояла осторонь цього процесу. Порядок денний сесії Ради ВУАН від 28-30 березня 1932 р. містив низку питань, пов'язаних із планами на другу п'ятирічку (Протокол, 1932: 37-30). На засіданні цієї сесії була присутня й делегація робітників уже з м. Макіївка, представник якої в своїй доповіді відзвітувався про зростання економічних показників основних галузей промисловості регіону, зосередивши увагу на необхідності продовження активної співпраці з установами ВУАН 
у галузі металургійного виробництва, вирішенні проблем коксування вугілля, механізації вугільної галузі, геологічних досліджень, а надто на вирішенні проблеми загазованості потужних пластів вугілля та удосконалення техніки безпеки на вугільних виробництвах (Протокол, 1932: 71-72). Значну частку завдань щодо вирішення питань, пов'язаних із вугільною галуззю, розробляв Державний Макіївський науково-дослідний інститут із безпеки гірничих робіт і гірничорятувальної справи, про що свідчить доповідь представника цього інституту. Але обмеженість ресурсів, нестача фахових спеціалістів і необхідність залучення спеціалістів із суміжних дисциплін для розвитку науковоприкладних досліджень спонукала інститут шукати шляхи налагодження тіснішої співпраці з науковими установами ВУАН.

До проблем екології Донбасу звернувся академік О.В. Фомін у доповіді “Проблема зазеленення робітничих міст та селищ”, зауваживши необхідність продовження цієї роботи у промисловому регіоні та, зокрема, у швидко зростаючих промислових містах Сталіно та Макіївці. Членами дендрологічної комісії М.В. Дубовиком і Р.Т. Кравченком унаслідок більш ніж двомісячної роботи в м. Сталіно був складений п'ятирічний план озеленення міста (Протокол, 1932: 58-66).

Підсумовуючи зазначимо, що масштабна співпраця двох регіонів відома як “Культурне шефство пролетарської громадськості Києва над Сталіно” розпочалась на хвилі українізації та першої п’ятирічки індустріалізації, коли через зростаючі потреби в продукції металургійної та вугільної промисловості вага промислового регіону Донбасу в Україні почала стрімко зростати. Реалізовуючись за кількома напрямами, шефство швидко трансформувалося з переважно освітнього та культурного в науково-практичний проект із допомоги у вирішенні практичних проблем розвитку промисловості, розвиток якої на Донбасі в роки першої п’ятирічки набирав обертів. У цій публікації поза увагою залишаємо роботу археологів та етнографів.

Вже у 1930 р. стало очевидним, що без втілення прогресивних проектів розвитку технологій витримати темпи реалізації планових завдань першої п’ятирічки неможливо. Приходить усвідомлення необхідності посилення ролі досягнень науки у подальшому розвиткові промисловості; поступово зростає роль наукових установ ВУАН у реалізації практичних завдань шефства. Хронологічно активна фаза реалізації шефської допомоги співпадає з роками першої п’ятирічки, у 1932 р. трансформуючись у формат соцзамовлень.

Незважаючи на те, що шефство мало численні недоліки: недостатній рівень планування, слабкий контроль за виконанням зобов'язань узятих на себе шефами, заідеологізованість культурної складової шефства, воно мало й значний позитивний результат. Не можна недооцінювати внесок культурних і освітніх установ Києва для покращення культурного життя мешканців регіону, підвищення рівня їх освіти. ВУАН як флагман української науки та її науковці зробили значний внесок у розвиток механізації промисловості регіону, покращення стану охорони праці, вивчення шкідливих умов на виробництві, поліпшення побутових умов проживання та покращення санітарних стандартів життя населення тощо. Окрім розвитку промисловості, діяльність науковців ВУАН сприяла розвиткові культурної сфери - появі мережі бібліотек і розбудові діяльності Сталінського окружного краєзнавчого музею.

Перспективним напрямом дослідження для поглиблення та деталізації інформації про участь установ ВУАН у допомозі Донбасу є опрацювання архівних документів наукових архівів установ, які брали безпосередню участь у реалізації наукової частини шефства й актуалізації роботи охоронних досліджень пам'яток археології на об’ єктах будівництва. 
Література:

2-га Всеукраїнська, 1929 - 2-га Всеукраїнська художня виставка Наркомосу УССР // Диктатура труда. 15 октября 1929. № 238 (2231).

16 июня, 1929 - 16 июня - пролетарский праздник украинской культуры // Приазовский пролетарий. 5 июня 1929. № 125 (947).

Академик Срезневский, 1929 - Академик Борис Измайлович Срезневский. Краткая биография // Диктатура труда. 30 июня 1929. № 148 (2141).

Академик Плотников, 1929 - Академик Владимир Александрович Плотников. Краткая биография // Диктатура труда. 30 июня 1929. № 148 (2141).

Академик Граве, 1929 - Академик Дмитрий Александрович Граве. Краткая биография // Диктатура труда. 26 июня 1929. № 144 (2137).

Академик Крылов, 1929 - Академик Николай Митрофанович Крылов. Краткая биография // Диктатура труда. 26 июня 1929. № 144 (2137)

Академик Тутковский, 1929 - Академик Павло Тутковский. Краткая биография // Диктатура труда. 21 июня 1929. № 140 (2133).

АН УССР, 1986 - Академия наук Украинской ССР. 1985. К., 1986. 383 с.

Багалей, 1929 - Багалей Д.И. Пролетариат выйдет победителем. Что тормозит украинизацию масс. Открытое письмо академика Багалея к рабочим Сталинщины // Диктатура труда. 5 апреля 1929. № 77 (2070). Берсен, 1930 - Берсен О. Стан і перспективи спільної роботи пролетарів та наукових робітників Київщини коло підсилення пролетарського впливу на будування української пролетарської науки // Вісті Всеукраїнської академії наук. Листопад-грудень 1930. № 6.

Бригада медциклу, 1931 - Бригада медциклу ВУАН на Сталінщині // Пролетарська правда. 25 липня 1931. № 167 (2980).

Бригади ВУАН, 1931 - Бригади ВУАН до Сталінщини, до Макіївщини // Пролетарська правда. 7 квітня 1931. № 87 (2891).

Бригадир, 1931 - Бригадир. На засіданні ради // Пролетарська правда. 25 березня 1931. № 67 (2880).

Вместо церковно-монархической агитации, 1929 - Вместо церковно-монархической агитации культурная работа. Во всеукраинском музейном городке // Диктатура труда. 2 июля 1929. № 149 (2142).

Выступаем в поход, 1929 - Выступаем в поход! Сегодня начало месячника украинской культуры // Диктатура труда. 5 апреля 1929. № 77 (2070).

Граве, 1929 - Граве Д.О. Математик-інженер-робітник. Значення математики у виробництві // Диктатура труда. 21 июня 1929. № 140 (2133).

Громадська робота, 1929 - Громадська робота ВУАН. Договір культурного шефства Києва над Сталіном // Вісті Всеукраїнської академії наук. Травень-червень 1929. № 5-6.

Давайте выполнять договор, 1929 - Давайте выполнять договор // Диктатура труда. 8 мая 1929. № 102 (2095).

Денисенко, Шапошнік, 1931 - Денисенко В., Шапошнік С. Можливості великі, а наслідки мізерні // Пролетарська правда. 14 червня 1931. № 133 (2946).

Смченко, Цупик, Харкін, 1931 - Смченко, Цупик, Харкін. Від плянів до соціялістичних метод роботи // Пролетарська правда. 14 червня 1931. № 133 (2946).

Жуков, 1929 - Жуков Г. Ходоки пролетарской Луганшины. На приеме у руководителей профдвижения на Украине // Луганская правда. 16 марта 1929. № 60 (3466).

Звідомлення, 1930 - Звідомлення представника від ВУАН, що їздив до м. Сталіного на першотравневі свята у складі робітничої делегації м. Києва // Вісті Всеукраїнської академії наук. Березень-квітень 1930. № 2.

Зельдович, Чернявський, 1931 - Зельдович, Чернявський. За культешельон "Пролетарської Правди" // Пролетарська правда. 25 березня 1931. № 67 (2880). С. 3.

Исторический поход, 1929 - Исторический поход пролетариев Сталинщины // Диктатура труда. 4 мая 1929. № 100 (2093).

История АН УССР, 1979 - История Академии наук Украинской ССР. К., 1979. 836 с.

Іваницький, 1930 - Іваницький І. Шефська робота ВУАН на новому етапі // Вісті Всеукраїнської академії наук. Листопад-грудень 1930. № 6.

Киевские культшефы, 1929 - Киевские культшефы участвуют в двухнедельнике // Диктатура труда. 13 сентября 1929. № 211 (2204).

Киевские рабочие, 1929 - Киевские рабочие ждут сталинскую делегацию”, “Чего мы ждем от поездки в Киев. Наш наказ делегатам // Диктатура труда. 28 апреля 1929. № 97 (2090).

Крапля, 1929 - Крапля О. Украинскую культуру несем в пролетарский Донбасс. Наша делегация в столице Украины. Беседа с наркомом // Луганская правда. 15 марта 1929. № 59 (3465).

Культробота на допомогу, 1931 - Культробота на допомогу реконструкції Донбасу // Пролетарська правда 23 листопада 1931. № 265 (3078).

Культурное шефство над Сталино, 1929 - Культурное шефство над Сталино // Киевский пролетарий. 13 июня 1929. № 133 (1198).

Культурное шефство над Сталинщиной, 1929 - Культурное шефство над Сталинщиной // Киевский пролетарий. 24 мая 1929. № 116(1181). 
Лекційно-популяризаційна робота ВУАН, 1930 - Лекційно-популяризаційна робота ВУАН // Вісті Всеукраїнської академії наук. Листопад-грудень 1930. № 6.

Лицем до Донбасу, 1931 - Лицем до Донбасу. Дванадцятого квітня культешельон “Пролетарської правди” вирушає. Озброймо всесоюзну кочегарку пролетарською культурою // Пролетарська правда. 7 квітня 1931. № 87 (2891).

Луганский, 1929 - Луганский. Поход 80-ти // Луганская правда. 10 марта 1929. № 56 (3462).

Матвєєва, 2003 - Матвєєва Л. Нариси з історії Всеукраїнської академії наук: монографія. К., 2003. 294 с. Месячник украинской культуры, 1929 - Месячник украинской культуры. Проверка украинизации // Приазовский пролетарий. 15 марта 1929. № 61 (883).

Наука на допомогу, 1931 - Наука на допомогу механізації // Пролетарська правда. 7 квітня 1931. № 87 (2891).

НА ІА НАНУ - Науковий архів Інституту археології НАН України.

Наш досвід, 1931 - Наш досвід // Пролетарська правда. 25 березня 1931. № 67 (2880).

Новий договір, 1930 - Новий соціялістичний договір на проведення культшефства Київ-СталіноМакіївка, що його підписано в Києві на урочистих зборах в Колонній Залі Палацу Праці в ХІІІ річницю жовтня 8/XI. 1930 року // Вісті Всеукраїнської академії наук. Листопад-грудень 1930. № 6.

Первомайские гости, 1929 - Первомайские гости киевского пролетариата. Культурный поход рабочих Донбасса. За овладение украинской культурой. 600 пролетариев-сталинцев прибыли в Киев // Киевский пролетарий. 30 апреля 1929. № 99(1164).

Познакомим, 1929 - Познакомим с украинским театром // Диктатура труда. 7 апреля 1929. № 79 (2072).

Полонська-Василенко, 1955 - Полонська-Василенко Н. Українська Академія наук: нарис історії. Частина I 1918-1930: монографія. Мюнхен. 1955. 150 с.

Полонська-Василенко, 1958 - Полонська-Василенко Н. Українська Академія наук: нарис історії. Частина II 1931-1941: монографія. Мюнхен. 1958. 214 с.

Принь, 2014 - Принь М.О. До історії музейної справи в Сталінській окрузі в 1920-х - на початку 1930х років // Праці Центру пам’яткознавства : зб. наук. праць. 2014. Вип. 26. С. 157-165.

Принь, Принь, 2015 - Принь О.В., Принь М.О. Листування у науковому співтоваристві: три листи Олександра Якубського до Петра Курінного // Матеріали і дослідження археології Прикарпаття і Волині. 2015. Вип. 19. С. 261-266.

Про стан, 1930 - Про стан та перспективи шефської роботи над Сталінщиною. Резолюція урочистих зборів, присвячених річниці культзв’язку Сталінщини з Київщиною // Диктатура труда. 7 мая 1930. № 106 (2310). Пролетарии Донбаса, 1929 - Пролетарии Донбасса, на аванпосты украинизации! В ряды строителей украинской культуры. Луганские рабочие и рабкоры в Харькове // Луганская правда. 12 марта 1929. № 57 (3463).

Пролетарі Сталінщини, 1931 - Пролетарі Сталінщини дають урочисту обіцянку країні Рад і своєму шефові - пролетаріятові Києва по ударницьки виконати свої промфінпляни вугілля й металю // Пролетарська правда. 27 січня 1931. № 21 (2834).

Пролетарский Киев, 1929 - Пролетарский Киев должен помочь // Диктатура труда. 7 апреля 1929. № 79 (2072).

Протокол, 1932 - Протокол сесії ради ВУАН 28-30 березня 1932 р. // (4-73) Вісті Всеукраїнської академії наук. Березень-квітень 1932. № 2 .

Протокол, 1929 - Протокол Ч. 5/9 від 13 травня 1929 р. звичайних зборів ради Всеукраїнської Академії

Наук // Вісті Всеукраїнської академії наук. Травень-червень 1929. № 5-6.

Советский Киев, 1929 - Советский Киев - культурный шеф Сталина // Киевский пролетарий. 4 мая 1929. № 101 (1166).

Союз индустрии, 1929 - Союз индустрии и культуры // Диктатура труда. 4 июля 1929. № 151 (2144).

Сталинские делегаты, 1929 - Сталинские делегаты во всеукраинском музейном городке // Диктатура труда. 2 июля 1929. № 149 (2142).

Творец электрификации, 1929 - Творец электрификации. Вице-президент Всесоюзной Академии Наук тов. Г.М. Кржижановский // Диктатура труда. 14 июля 1929. № 159 (2152).

Теоретик, 1929 - Теоретик национальной проблемы. Тов. Н.А. Скрыпник // Диктатура труда. 14 июля 1929. № 159 (2152).

Торжество, 1929 - Торжество украинской и советской культуры. Киевская рабочая делегация возвратилась из Сталино // Киевский пролетарий. 20 июня 1929. № 139 (1204).

Три дні, 1929 - Три дні в Києві // Диктатура труда. 5 июля 1929. № 152 (2145).

Украинские писатели, 1929 - Украинские писатели на Сталинщине // Диктатура труда. 23 марта 1929. № 66 (2059).

Украинские ученые, 1929 - Украинские ученые и академики в Донбассе // Приазовский пролетарий. 19 октября 1929. № 242 (1603).

Фомін, 1929 - Фомін О.В. Ботаніка на службі народньому господарству // Диктатура труда. 30 июня 1929. № 148 (2141).

Хребтов, 1929 - Хребтов М. Два Донбасса // Диктатура труда. 8 мая 1929. № 102 (2095). 
Хуторян, 1931 - Хуторян А. Київський культешелон повернувся з Донбасу // Пролетарська правда. 24 січня 1931. № 19 (2832).

Цейтлин, 1929 - Цейтлин. Симфония Донбасса // Диктатура труда. 24 ноября 1929. № 271 (2264).

ЦДАВО України - Центральний державний архів вищих органів влади та управління України.

Шах, 1929 - Шах В. Перед выборами в ВУАН. Массы и наука в контакте // Диктатура труда. 9 июня 1929. № 130 (2123).

\section{References:}

2-ha Vseukrayins'ka, 1929 - 2-ha Vseukrayins'ka khudozhnya vystavka Narkomosu USSR [2nd AllUkrainian Art Exhibition of the People’s Commissariat of Education of the USSR] // Diktatura truda. 1929. № 238 (2231). [in Ukrainian].

16 iyunya, 1929 - 16 iyunya - proletarskiy prazdnik ukrainskoy kul'tury [June 16 is the proletarian holiday of Ukrainian culture] // Priazovskiy proletariy. 1929. № 125 (947). [in Russian].

Akademik Sreznevskiy, 1929 - Akademik Boris Izmaylovich Sreznevskiy. Kratkaya biografiya [Academician Boris Izmailovich Sreznevsky. Short biography] // Diktatura truda. 1929. № 148 (2141). [in Russian].

Akademik Plotnikov, 1929-Akademik Vladimir Aleksandrovich Plotnikov. Kratkaya biografiya [Academician Vladimir Alexandrovich Plotnikov. Short biography] // Diktatura truda. 1929. № 148 (2141). [in Russian].

Akademik Grave, 1929 - Akademik Dmitriy Aleksandrovich Grave. Kratkaya biografiya [Academician Dmitry Alexandrovich Grave. Short biography] // Diktatura truda. 1929. № 144 (2137). [in Russian].

Akademik Krylov, 1929 - Akademik Nikolay Mitrofanovich Krylov. Kratkaya biografiya [Academician Nikolai Mitrofanovich Krylov. Short biography] // Diktatura truda. 1929. № 144 (2137). [in Russian].

Akademik Tutkovskiy, 1929 - Akademik Pavlo Tutkovskiy. Kratkaya biografiya [Academician Pavlo Tutkovsky. Short biography] // Diktatura truda. 1929. № 140 (2133). [in Russian].

AN USSR, 1986 -Akademiya nauk Ukrainskoy SSR. 1985 [Academy of Sciences of the Ukrainian SSR]. K., 1986. 383 s. [in Russian].

Bagaley, 1929 - Bagaley D. I. Proletariat vyydet pobeditelem. Chto tormozit ukrainizatsiyu mass. Otkrytoe pis'mo akademika Bagaleya k rabochim Stalinshchiny [The proletariat will emerge victorious. What hinders the Ukrainization of the masses. Open letter of Academician Bagaley to the workers of Stalin region] // Diktatura truda. 1929. № 77 (2070). [in Russian].

Bersen, 1930 - Bersen O. Stan i perspektyvy spil'noyi roboty proletariv ta naukovykh robitnykiv Kyyivshchyny kolo pidsylennya proletars'koho vplyvu na buduvannya ukrayins'koyi proletars'koyi nauky [The state and prospects of the joint work of the proletarians and scholars of the Kyiv region on the strengthening of the proletarian influence on the building of the Ukrainian proletarian science] // Visti Vseukrayins'koyi akademiyi nauk. 1930. № 6. [in Ukrainian].

Bryhada medtsyklu, 1931 - Bryhada medtsyklu VUAN na Stalinshchyni [The All-Ukrainian Academy of Sciences’ Medycle Brigade in Stalin region] // Proletars'ka pravda. 1931. № 167 (2980). [in Ukrainian].

Bryhady VUAN, 1931 - Bryhady VUAN do Stalinshchyny, do Makiyivshchyny [The All-Ukrainian Academy of Sciences' Brigade - The All-Ukrainian Academy of Sciences' Brigade to Stalin region and Makeevka region] // Proletars'ka pravda. 1931. № 87 (2891). [in Ukrainian].

Bryhadyr, 1931 - Bryhadyr. Na zasidanni rady [At a council meeting] // Proletars'ka pravda. 1931. № 67 (2880). [in Ukrainian].

Vmesto tserkovno-monarkhicheskoy agitatsii, 1929 - Vmesto tserkovno-monarkhicheskoy agitatsii kul'turnaya rabota. Vo vseukrainskom muzeynom gorodke [Instead of church-monarchist agitation, cultural work. In the All-Ukrainian Museum Town] // Diktatura truda. 1929. № 149 (2142). [in Russian].

Vystupaem v pokhod, 1929 - Vystupaem v pokhod! Segodnya nachalo mesyachnika ukrainskoy kul'tury [We are on the hike! Today is the beginning of the month of Ukrainian culture] // Diktatura truda. 1929. № 77 (2070). [in Russian].

Hrave, 1929 - Hrave D. O. Matematyk-inzhener-robitnyk. Znachennya matematyky u vyrobnytstvi [Mathematician-engineer-worker. The value of mathematics in production] // Diktatura truda. 1929. № 140 (2133). [in Ukrainian].

Hromads'ka robota, 1929 - Hromads'ka robota VUAN. Dohovir kul'turnoho shefstva Kyyeva nad Stalinom [Public work of All-Ukrainian Academy of Sciences. Contract of cultural patronage of Kiev region over Stalin region] // Visti Vseukrayins’koyi akademiyi nauk. 1929. № 5-6. [in Ukrainian].

Davayte vypolnyat' dogovor, 1929 - Davayte vypolnyat' dogovor [Let's fulfill the contract] // Diktatura truda. 1929. № 102 (2095). [in Russian].

Denysenko, Shaposhnik, 1931 - Denysenko V., Shaposhnik S. Mozhlyvosti velyki, a naslidky mizerni [The possibilities are large, and the consequences are scarce] // Proletars’ka pravda. 1931. № 133 (2946). [in Ukrainian].

Yemchenko, Tsupyk, Kharkin, 1931 - Yemchenko, Tsupyk, Kharkin. Vid plyaniv do sotsiyalistychnykh metod roboty [From plans to a socialist method of work] // Proletars'ka pravda. 1931. № 133 (2946). [in Ukrainian].

Zhukov, 1929-Zhukov G. Khodoki proletarskoy Luganshchini. Na prieme u rukovoditeley profdvizheniya na Ukraine [Proletarians of Lugansk region. At a reception at the leaders of the trade union movement in Ukraine] // Luganskaya pravda. 1929. № 60 (3466). [in Russian]. 
Zvidomlennya, 1930 - Zvidomlennya predstavnyka vid VUAN, shcho yizdyv do $\mathrm{m}$. Stalinoho na pershotravnevi svyata u skladi robitnychoyi delehatsiyi m. Kyyeva [Report of the representative from the AllUkrainian Academy of Sciences who traveled to Stalin region in the Kyiv working delegation on May Day holidays] // Visti Vseukrayins’koyi akademiyi nauk. 1930. № 2. [in Ukrainian].

Zel'dovych, Chernyavs'kyy, 1931 - Zel'dovych, Chernyavs'kyy. Za kul'teshel'on "Proletars'koyi Pravdy" [For the cultural echelon of "Proletars 'ka pravda"] // Proletars’ka pravda. 1931. № 67 (2880). [in Ukrainian].

Istoricheskiy pokhod, 1929 - Istoricheskiy pokhod proletariev Stalinshchiny [Historical campaign proletarians Stalin region] // Diktatura truda. 1929. № 100 (2093). [in Russian].

Istoriya AN USSR, 1979 - Istoriya Akademii nauk Ukrainskoy SSR. [History of the Academy of Sciences of the Ukrainian SSR] K., 1979. 836s. [in Russian].

Ivanyts'kyy, 1930 - Ivanyts'kyy I. Shefs'ka robota VUAN na novomu etapi [The work of All-Ukrainian Academy of Sciences at the new stage] // Visti Vseukrayins'koyi akademiyi nauk. 1930. № 6. [in Ukrainian].

Kievskie kul'tshefy, 1929 - Kievskie kul'tshefy uchastvuyut v dvukhnedel'nike [Kiev chefs participate in the fortnight] // Diktatura truda. 1929. № 211 (2204). [in Russian].

Kievskie rabochie, 1929 - Kievskie rabochie zhdut stalinskuyu delegatsiyu", "Chego my zhdem ot poezdki v Kiev. Nash nakaz delegatam [Kiev workers are waiting for the delegation from Stalin region, "What do we expect from a trip to Kiev". Our instructions to delegates] // Diktatura truda. 1929. № 97 (2090). [in Russian].

Kraplya, 1929 - Kraplya O. Ukrainskuyu kul'turu nesem v proletarskiy Donbass. Nasha delegatsiya v stolitse Ukrainy. Beseda s narkomom [Ukrainian culture carry in the proletarian Donbass. Our delegation in the capital of Ukraine. Conversation with the People’s Commissar] // Luganskaya pravda. 1929. № 59 (3465). [in Russian].

Kul'trobota na dopomohu, 1931 - Kul'trobota na dopomohu rekonstruktsiyi Donbasu [Culture for the reconstruction of the Donbas] // Proletars'ka pravda 1931. № 265 (3078). [in Ukrainian].

Kul'turnoe shefstvo nad Stalino, 1929 - Kul'turnoe shefstvo nad Stalino [Cultural patronage over Stalino] // Kievskiy proletariy. 1929. № 133 (1198). [in Russian].

Kul'turnoe shefstvo nad Stalinshchinoy, 1929 - Kul'turnoe shefstvo nad Stalinshchinoy [Cultural patronage over Stalin region] // Kievskiy proletariy. 1929. № 116 (1181). [in Russian].

Lektsiyno-populyaryzatsiyna robota VUAN, 1930 - Lektsiyno-populyaryzatsiyna robota VUAN [Lecture-popularization work of All-Ukrainian Academy of Sciences] // Visti Vseukrayins'koyi akademiyi nauk. 1930. № 6. [in Ukrainian].

Lytsem do Donbasu, 1931 - Lytsem do Donbasu. Dvanadtsyatoho kvitnya kul'teshel'on “Proletars'koyi pravdy" vyrushaye. Ozbroymo vsesoyuznu kocheharku proletars'koyu kul'turoyu [Face to Donbass. On April 12 , the cultural echelon of the "Proletars"ka pravda" goes. We will equip the all-Union steamshop with a proletarian culture] // Proletars'ka pravda. 1931. № 87 (2891). [in Ukrainian]. Russian].

Luganskiy, 1929 - Luganskiy. Pokhod 80-ti [Hike of eighty] // Luganskaya pravda. 1929. № 56 (3462). [in

Matvyeyeva, 2003 - Matvyeyeva L. Narysy z istoriyi Vseukrayins'koyi akademiyi nauk: monohrafiya [Essays on the history of the All-Ukrainian Academy of Sciences]. K., 2003. 294 s. [in Ukrainian].

Mesyachnik ukrainskoy kul'tury, 1929 - Mesyachnik ukrainskoy kul'tury. Proverka ukrainizatsii [Month of Ukrainian culture. Verification of Ukrainization] // Priazovskiy proletariy. 1929. № 61 (883). [in Russian].

Nauka na dopomohu, 1931 - Nauka na dopomohu mekhanizatsiyi [Science to help mechanization] // Proletars'ka pravda. 1931. № 87 (2891). [in Ukrainian].

NA IA NANU - Naukovyy arkhiv Instytutu arkheolohiyi NAN Ukrayiny [Scientific archive of the Institute of Archeology of the National Academy of Sciences of Ukraine].

Nash dosvid, 1931 - Nash dosvid [Our experience] // Proletars’ka pravda. 1931. № 67 (2880). [in Ukrainian].

Novyy dohovir, 1930 - Novyy sotsiyalistychnyy dohovir na provedennya kul'tshefstva Kyyiv-StalinoMakiyivka, shcho yoho pidpysano v Kyyevi na urochystykh zborakh v Kolonniy Zali Palatsu Pratsi v XIII richnytsyu zhovtnya 8/XI. 1930 roku [A new socialist agreement for carrying the cultural patronage of KyivStalino-Makeyevka, which was signed in Kiev at a solemn assembly in the Column Hall of the Palace of Labor on the thirteenth anniversary of October 8/XI. 1930] // Visti Vseukrayins'koyi akademiyi nauk. 1930. № 6. [in Ukrainian]. Pervomayskie gosti, 1929 - Pervomayskie gosti kievskogo proletariata. Kul'turnyy pokhod rabochikh Donbassa. Za ovladenie ukrainskoy kul'turoy. 600 proletariev-stalintsev pribyli v Kiev [May Day guests of the Kiev proletariat. Cultural hike of workers of Donbass. For the mastery of Ukrainian culture. 600 proletarian from Stalino arrived in Kiev] // Kievskiy proletariy. 1929. № 99(1164). [in Russian].

Poznakomimsya, 1929 - Poznakomim s ukrainskim teatrom [Let's get acquainted with the Ukrainian theater] // Diktatura truda. 1929. № 79 (2072). [in Russian].

Polons'ka-Vasylenko, 1955 -Polons'ka-Vasylenko N. Ukrayins'ka Akademiya nauk : narys istoriyi. Chastyna I 1918-1930 [Ukrainian Academy of Sciences: an essay of history. Part I 1918-1930]. Myunkhen. 1955. 150 s. [in Ukrainian].

Polons'ka-Vasylenko, 1958-Polons'ka-Vasylenko N. Ukrayins'kaAkademiya nauk : narys istoriyi. Chastyna II 19311941 [Ukrainian Academy of Sciences: an essay of history. Part II 1931-1941]. Myunkhen. 1958. 214 s. [in Ukrainian].

Pryn', 2014 - Pryn' M. O. Do istoriyi muzeynoyi spravy v Stalins'kiy okruzi v 1920-kh - na pochatku 1930kh rokiv [The history of museology in Stalin's region in the 1920's - early 1930's] // Pratsi Tsentru pam"yatkoznavstva: zb. nauk. prats'. 2014. Vyp. 26. C. 157-165. [in Ukrainian]. 
Pryn', Pryn', 2015 - Pryn’ O. V., Pryn’ M O. Lystuvannya u naukovomu spivtovarystvi: try lysty Oleksandra Yakubs'koho do Petra Kurinnoho [Correspondence in the scientific community: three letters from Olexandr Yakubsky to Petro Kurinny] // Materialy i doslidzhennya arkheolohiyi Prykarpattya i Volyni. 2015. Vyp. 19. C. 261266. [in Ukrainian].

Pro stan, 1930 - Pro stan ta perspektyvy shefs'koyi roboty nad Stalinshchynoyu. Rezolyutsiya urochystykh zboriv, prysvyachenykh richnytsi kul'tzv"yazku Stalinshchyny z Kyyivshchynoyu [About the state and prospects of patronage on the Stalin region. Resolution of the solemn meeting devoted to the anniversary of the cultural connection of the Stalin region with the Kyiv region] // Diktatura truda. 1930. № 106 (2310). [in Ukrainian].

Proletarii Donbasa, 1929 - Proletarii Donbassa, na avanposty ukrainizatsii! V ryady stroiteley ukrainskoy kul'tury. Luganskie rabochie i rabkory v Khar'kove [Proletarians of Donbass, on the outposts of Ukrainianization! In the ranks of Ukrainian culture builders. Lugansk workers and worker correspondents in Kharkiv] // Luganskaya pravda. 1929. № 57 (3463). [in Russian].

Proletari Stalinshchyny, 1931 - Proletari Stalinshchyny dayut' urochystu obitsyanku krayini Rad i svoyemu shefovi - proletariyatovi Kyyeva po udarnyts'ky vykonaty svoyi promfinplyany vuhillya y metalyu [The proletarians of the Stalin region give a solemn promise to the Soviets and to their shefs - proletarians of Kyiv region to implement the plans of coal and metal] // Proletars'ka pravda. 1931. № 21 (2834). [in Ukrainian].

Proletarskiy Kiev, 1929 - Proletarskiy Kiev dolzhen pomoch' [Proletarian Kiev must help] // Diktatura truda. 1929. № 79 (2072). [in Russian].

Protokol, 1932 - Protokol sesiyi rady VUAN 28-30 bereznya 1932 r. [Protocol of the All-Ukrainian Academy of Sciences' Council session on march 28-30, 1932] // Visti Vseukrayins'koyi akademiyi nauk. 1932. № 2. [in Ukrainian].

Protokol, 1929 - Protokol Ch. 5/9 vid 13 travnya 1929 r. zvychaynykh zboriv rady Vseukrayins'koyi Akademiyi Nauk [Protocol Ch. 5/9 of May 13, 1929, of the ordinary meeting of the of the All-Ukrainian Academy of Sciences' Council] // Visti Vseukrayins'koyi akademiyi nauk. 1929. № 5-6. [in Ukrainian].

Sovetskiy Kiev, 1929 - Sovetskiy Kiev - kul'turnyy shef Stalina [Soviet Kiev - the cultural chief of Stalino] // Kievskiy proletariy. 1929. № 101 (1166). [in Russian].

Soyuz industrii, 1929 - Soyuz industrii i kul'tury [Union of Industry and Culture] // Diktatura truda. 1929. № 151 (2144). [in Russian].

Stalinskie delegaty, 1929 - Stalinskie delegaty vo vseukrainskom muzeynom gorodke [Delegates from Stalino is in the All-Ukrainian Museum Town] // Diktatura truda. 1929. № 149 (2142). [in Russian].

Tvorets elektrifikatsii, 1929 - Tvorets elektrifikatsii. Vitse-prezident Vsesoyuznoy Akademii Nauk tov.

G.M. Krzhizhanovskiy [Creator of electrification. Vice-President of the All-Union Academy of Sciences G.M.Krzhizhanovsky] // Diktatura truda. 1929. № 159 (2152). [in Russian].

Teoretik, 1929 - Teoretik natsional'noy problemy. Tov. N.A. Skrypnik [Theorist of the national problem. N.A. Skrypnik] // Diktatura truda. 1929. № 159 (2152). [in Russian].

Torzhestvo, 1929 - Torzhestvo ukrainskoy i sovetskoy kul'tury. Kievskaya rabochaya delegatsiya vozvratilas' iz Stalino [The triumph of Ukrainian and Soviet culture. Kiev workers delegation returned from Stalino] // Kievskiy proletariy. 1929. № 139 (1204). [in Russian].

Try dni, 1929 - Try dni v Kyevi [Three days in Kiev] // Diktatura truda. 1929. № 152 (2145). [in Ukrainian]. Ukrainskie pisateli, 1929 - Ukrainskie pisateli na Stalinshchine [Ukrainian writers in Stalin region] // Diktatura truda. 1929. № 66 (2059). [in Russian].

Ukrainskie uchenye, 1929 - Ukrainskie uchenye i akademiki v Donbasse [Ukrainian scientists and academics in the Donbass] // Priazovskiy proletariy. 1929. № 242 (1603). [in Russian].

Fomin, 1929 - Fomin O. V. Botanika na sluzhbi narodn'omu hospodarstvu [Botany in the service of the national economy] // Diktatura truda. 1929. № 148 (2141). [in Ukrainian]. Russian].

Khrebtov, 1929 - Khrebtov M. Dva Donbassa [Two Donbass] // Diktatura truda. 1929. № 102 (2095). [in

Khutoryan, 1931 - Khutoryan A. Kyyivs'kyy kul'teshelon povernuvsya z Donbasu [Kiev cultural echelon returned from Donbass] // Proletars’ka pravda. 1931. № 19 (2832). [in Ukrainian].

Tseytlin, 1929 - Tseytlin. Simfoniya Donbassa [Symphony of Donbass] // Diktatura truda. 1929. № 271 (2264). [in Russian].

TsDAVOU - Tsentral'nyy derzhavnyy arkhiv vyshchykh orhaniv vlady ta upravlinnya Ukrayiny [Central State Archive of the Supreme Governance and Management of Ukraine].

Shakh, 1929 - Shakh V. Pered vyborami v VUAN. Massy i nauka v kontakte [Before the election to AllUkrainian Academy of Sciences. Mass and science in contact] // Diktatura truda. 1929. № 130 (2123). [in Russian].

Отримано 11.09.2018 